reason fresh cow's milk is, to be regarded with suspicion or is unobtainable. In these circumstances the food may be recommended having regard to the above analytical results.

\section{STERILLA SOAP.}

(Harold E. Matmhews, The Malu Pharmacy, Cimfton, Bristor.)

Sterilla is described as a liquid soap suitable particularly for surgical and medical purposes. According to our analysis it contains more than one antiseptic substance and bacteriological examination assigns to it a carbolic coefficient of 1 by the Rideal-Walker method. It is non-corrosive and relatively speaking non-poisonous, though of course a powerful germicide. Moreover, it is agreeable to use, the materials having been put together skilfully and with care. In addition to its germicidal properties Sterilla is also a satisfactory detergent.

VIN DE GRAVES SUPÉRIEUR.

(Hatch, Mangfield, and Co., 47, Pali, Male, London, S.W.)

This is a sound light wine of the Graves type. It possesses a peculiarly delicate and pleasing flavour. Analysis gave the following results: alcohol, by volume, $11 \cdot 70$ per cent. ; extractives, 2.02 per cent. ; mineral matter, 0.32 per cent. ; volatile acidity reckoned as acetic acid, $0 \cdot 14$ per cent. ; fixed acidity reckoned as tartaric acid, 0.59 per cent. ; and sugar, 1.56 per cent. The wine is thus suitable for dietetic purposes, affording an agreeable contrast to the full-bodied wines.

\section{GUAIACOSE}

(The Bayer Co., Lmmted, 19, St. Duns'can's-hile, London, E.C.) Guaiacose contains somatose (a preparation consisting chiefly of albumose) and calcium guaiacol-sulphonate which is a practically tasteless form of guaiacol. According to our analysis the syrup contains 8.07 per cent. of proteins precipitatable by bromine. The total nitrogen, however, amounts to 2 per cent., which would give the total nitrogenous substances as $12 \cdot 60$ per cent. The mineral matter amounted to 3.41 per cent. The preparation presents nutritive and antiseptic properties and its use is suggested in wasting diseases and in convalescence from disease. It is also said to prevent catarrh following respiratory disease while in certain gastric disorders guaiacol is known to be of advantage.

\section{FORMITROL PASTILLES.}

(A. WaAter, 1 \& 3, Leonard-Street, City-road, LoNdon, E.C.)

Formitrol pastilles when dissolved in the month yield formaldehyde, the method of administration being effective in septic conditions of the mouth. The pastilles contain formaldehyde, menthol, citric acid, and milk sugar. Clinical results justify the statements made in regard to the bactericidal effects of these pastilles, as, for example, in sore throat and catarrh.

\section{(1) TABLET GLYCEROPHOSPHATE WITH HÆMOGLOBIN} AND (2) SOLTABS.

(C. J. HewletT and Son, 35-42, Charlotte-street, London, E.C.)

(1) The tablets containing the glycerophosphates with hæmoglobin present an excellent formula and the combination also is an elegant one from the pharmacentical point of view. Each tablet contains glycerophosphate of calcium one grain, glycerophosphate of potassium half a grain, glycerophosphate of sodium half a grain, glycerophosphate of iron one-quarter of a grain, and glycerophosphate of magnesium half a grain, caffeine citrate half a grain, strychnine hydrochloride 1-80th of a grain, and hæmoglobin one grain. These ingredients respectively were readily recognised on analysis. The formula is designed for cases of anæmia-in short, for the treatment of bloodless conditions generally and especially in growing children. (2) There are also many excellent formulæ contained in the "soltab" which is a compressed tablet designed for the ready preparation of various soulutions. Amongst those which may be mentioned are a borax compound, a nasal alkaline and antiseptic combination, and eucaine and adrenalin.

(1) POTENOL; (2) HANOLINE'; AND (3) LICKOLEUM.

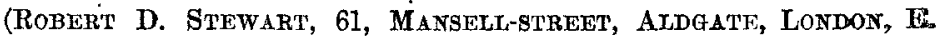

All the three above preparations are well adapted for certain obvious hygienic purposes. Potenol is a concentrated alkaline preparation of phenols which gives a milky emulsion with water, Hanoline is an excellent detergent and is specially adapted for removing grease and grime, while Lickoleum is a liquid soap adapted for cleaning painted, enamelled, and varnished surfaces. These preparations supply in a satisfactory way wants frequently felt in household experience.

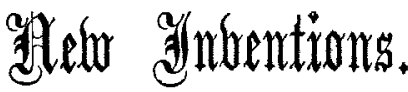

\section{A NEW FEMALE URETHRAL CATHETER.}

SOME time ago I required to empty the bladder of a patient on the second day after her confinement with forceps, and on cleansing the orifice of the urethra the vestibule bled freely from some superficial lacerations of its surface. On introducing an ordinary female catheter I found its lomen had become blocked with blood-clot. To prevent thi occurrence the catheter shown in the illustrations was made to my specification by Messrs. James Woolley, Sons, and Co., Limited, of Manchester. It is a round, silver-plated, or bright metal curved tube seen in Fig. 2, which is open at both ends, and is of the size of a No. 10 male catheter. As its curve is uniform a solid metal guide with a bulbous handle, shown in Fig. 3, can be placed in its interior so as to fill it accurately and to project just beyond its bladder en as Fig. 1 shows. This guide bar is useful for several purposes. First, it not only adds sufficient weight to the tube but provides its bladder end with a smooth and romol extremity, so that its introduction is easy and its passage is painless. Secondly, by fitting its lumen accurately it closes up the two lateral openings as well as the one at the point, which when open freely admit the urine and any sediment in the bladder, so that no only is the entrance of blood with the consequent bloeking up of its lumen during its introduction prevented,
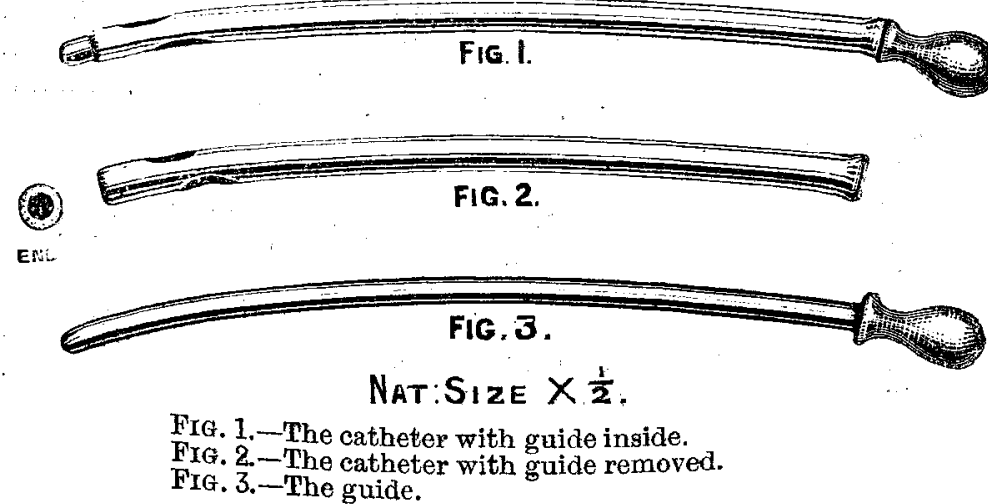

but it also prevents the escape of urine until a receptacle is at hand, when it is withdrawn from the tube, the curve of which then projects the stream of urine accurately into the receptacle placed beneath it. Thirdly, after the catheter has been washed and boiled, its interior can be dried by using. the guide bar to push a little plug of sterile absorbent. cotton-wool through its lumen, after which the guide bar remaining inside the catheter prevents the access of dust to its interior, thus keeping it sterile. The price of the catheter is $3 s .6 d$.

Rock Ferry.

\section{F. S. Pitt-TAYLOR, M.B., Ch.B.Victo}

\section{A NEW SCALPEL CARRIER.}

SURGEONs have frequently agreed that the sterilisation of knives is better done by the application of some germicidal fluid, as boiling may affect a knife's edge and impair its cutting power. No method of application can have more simplicity and safeness than immersion. For surgeons called upon to operate pring pouses or in the country 
the "best means of carrying knives is a matter of interest. I have had made for me by Messrs. Down Brothers, Limited, an appliance which, while providing for the sterilisation of the knives by constant immersion in a sterilising fluid, provides a perfectly easy and satisfactory way of carrying them. It consists of a scalpel rack made to contain four knives held firmly in position with a bar which can be fixed by a lever clamp. The scalpel rack is fitted into
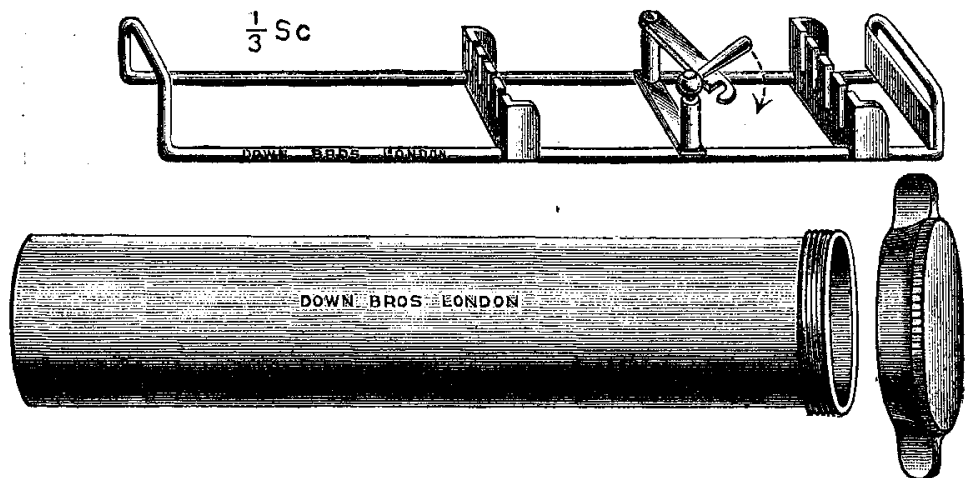

a metal tube 8 inches long by $1_{\frac{1}{2}}$ inches in diameter, which a screw-on lid renders air-proof. The knives are sterilised and kept sterile by the tube being nearly filled with a solution of 1 part of lysol in 12 of rectified spirit. By no amount of shaking in any position or direction can the edges or points of the scalpels come in contact with anything but the solution in which they are immersed. Each knife is thus kept sterile, does not rust, and retains its original sharpness unimpaired and its polish intact.

D. M. GREIG, C.M., F.R.C.S. Edin.,

Surgeon, Dundee Royal Infirmary, Royal Victoria Hospital, \&c.

\section{ROYAL COLLEGE OF PHYSICIANS OF LONDON.}

A Comitia was held on Oct. 29th, Sir R. Douglas Powell, Bart., K.C.V.O., the President, being in the chair.

The following gentlemen who had passed the required examination were admitted Members of the College :-Hugh Tuke Ashby, M.B. Cantab., L.R.C.P. Lond.; Haldinstein David Davis, M.B. Oxon., L. R.C.P. Lond. ; Harold Benjamin Day, M.D. Lond., L.R.C.P. Lond. ; Gordon Morgan Holmes, M.D. Dub. ; Charles Ernest Lakin, M.D. Lond., L.R.C.P. Lond. ; Archibald Carrie MacGilchrist, M.B. Edin. ; Otto May, M.B. Cantab. ; and William Southwick Willmore, L. R.C.P. Lond.

Licences to practise physic were granted to 94 gentlemen who had passed the necessary examinations. It was announced that the Jenks Scholarship had been gained by Mr. Ernest Haines Walker.

The following communications were received:-1. From the Chancellor of the University of Cambridge inviting the College to appoint a delegate to represent it at the commemoration of Charles Darwin, which will be held by the University in June, 1909. The Senior Censor (Dr. Norman Moore) was appointed to represent the College. 2. From the secretary of the Royal College of Surgeons of England reporting proceedings of the Council on July 30th and Oct. 15th. 3. From Dr. Henry Selfe Bennett, offering for the acceptance of the College a pastel portrait of his father, the late Sir J. Risdon Bennett, President of the College. The gift was accepted and the thanks of the College were ordered to be communicated to the donor.

The audited accounts for the year ending Sept. 29th last were received and adopted. The quarterly report of the finance committee, dated Oct. 22nd, was received and adopted.

The President, Senior Censor, Registrar (Dr. E. Liveing), Treasurer (Sir Dyce Duckworth), and the Harveian librarian (Dr. J. F. Payne) were appointed members of a committee to join five appointed by the Society of Arts for awarding the Swiney prize in January next. Sir William S. Church was re-appointed the representative of the College on the Council of University College, Bristol.

The Treasurer moved, and the Senior Censor seconded, a motion that the joint committee on the Examination Hall buildings be authorised to negotiate with the Institution of Electrical Engineers a temporary tenancy of rooms in the
Hall for examination purposes on terms to be approved by the Royal Colleges. The motion was adopted.

A report was received from the committee of management dated Oct. 6th. The committee recommended that the following institutions be added to the list of those recognised by the Examining Board in England for instruction in chemistry and physics : the Municipal Technical Institute, Portsmouth, and King's School, Canterbury. Also, that the Victoria Infirmary, Glasgow, be added to the list of general hospitals recognised by the Board. Also, that the University of Nebraska, United States, be added to the list of universities at which the curriculum of professional study required for the diplomas of the Royal Colleges may be pursued, and the graduates of which may be admitted to the final examination of the Examining Board in England on production of the required certificates of study. - The report was adopted.

Dr. Liveing was re-elected a member of the committee of management.

The books and other publications presented to the library during the past quarter were received and the thanks of the College were ordered to be returned to the donors. After some further formal business the PRESIDENT dissolved the Comitia.

\section{UNIVERSITY OF LONDON.}

\section{Meeting of the Faculty of Medicine.}

A MEETING of the Faculty of Medicine of the University of London was held at the University on Oct. 28th, Dr. J. K. Fow minutes of the last meeting having been read and confirmed the Faculty proceeded to the election of a dean for the period 1908-10. Professor Sidney H. C. Martin was unanimously elected to the position and took the chair which was vacated by Dr. Fowler. The recommendations with regard to the boards of studies for 1909 were approved.

A motion by Dr. LEONARD E. HILl, seconded by Dr. LAURISTON $E$. SHAW, was then put before the meeting. The recommendation was as follows:-

That the Faculty of Medicine, whilst cordially agreeing with the proposal of the University to divide the eurriculum more equally between the earlier and clinical studies, believes that it would be detrimental to the interests of the University to extend the five years' curriculum without securing the coöperation of the other universities and licensing without securing the cooperation of the other universities and licensing
bodies. The Faculty therefore urges upon the Senate the desirability boties. The Faculty therefore urges upon the Senate the desirability
of refraining from carrying into effect the regulation adding six months to the curriculum until further consideration has been given to the to the curriculum until further consideration has been given to the
matter and the other Universities and Licensing Bodies for whom the matter and the other Universities and Licensing Bodies for whom the
schools of medicine of the University prepare students have intimated schools of medicine of the University prepare students have intimated
their willingness to make a corresponding alteration in their regulations. their willingness to make a corresponding alteration in their regulations. no Faculty of Medicine also thinks it desirable to point out that it had no opportunity of expressing its opinion upon this, probably the most
important change in the medical curriculum since the reconstitution important change

As an amendment to this motion Sir Feutx Semon proposed, and Sir Thomas BARLOW seconded, the following :-

That the Faculty of Medicine, whilst regretting that it should not have had any opportunity of expressing its opinion upon the important change in the medical curriculum recently effected, before it was actually carried into law, welcomes the decision of the Senate, being convinced that the change will effect a great improvement in medical education in this country, and that other Universities and Licensing Bodies will follow the example set by the University of London.

After a long discussion, in which many of the members of the Faculty took part, the amendment was carried by a substantial majority, but on being put by the Chairman as a substantive motion the following amendment, proposed by Dr. W. P. HERRINGHAM, was carried in its place :-

That the Faculty of Medicine respectfully begs to state to the Senate that it greatly regrets that the Senate should not have thought fit before carrying out the important changes recently effected in the medical curriculum, to have consulted the Faculty thereon.

This amendment was adopted and passed as a substantive motion.

The Faculty then proceeded to the consideration of the following recommendation of the General Medical Council, referred to the Faculty by the Academic Council for report :-

That the attention 'of the licensing bodies be called to the necessity, In the public interest, of instituting clinical and practical examinations in midwifery and gynæcology in connexion with each of the qualifying examinations.

On the motion of Dr. H. L. EAson, seconded by Dr. HERRINGHAM, it was unanimously agreed that the subjects of midwifery and gynæcology are entirely unsuitable for clinical and practical examinations. 